\title{
Pengamalan Sila Kesatu Pancasila melalui Shalat Dzuhur Berjamaah sebagai Wahana Pendidikan Karakter
}

\author{
Raras Noviyanti ${ }^{1 *}$, Intan Rahmawati ${ }^{2}$ Suyitno $^{3}$ \\ ${ }^{123}$ Jurusan Pendidikan Guru Sekolah Dasar, Universitas PGRI Semarang, Semarang, Indonesia
}

\section{A R T I C L E I N F O \\ Article history: \\ Received 18 August 2019 \\ Received in revised form \\ 19 September 2019 \\ Accepted 25 October 2019 \\ Available online 30 \\ November 2019 \\ Kata Kunci: \\ Pancasila, Pendidikan \\ Karakter, Shalat Dzuhur \\ Berjamah \\ Keywords: \\ Pancasila, Character \\ Education, Praying Prayers}

\begin{abstract}
A B S T R A K
Latar belakang yang medorong penelitian ini adalah peneli ingin mengetahui bagaimana pengamalan sila kesatu Pancasila melalui shalat dzuhur berjamaah sebagai wahana pendidikan karakter SDN Tambakrejo 03 Semarang. Serta nilai karakter apa saja yang ditemukan dengan diadakannya kegiatan shalat dzuhur berjamaah di SDN Tambakrejo 03 Semarang.Metode penelitian deskriptif kualitatif. Sumber data penelitian yaitu siswa dan guru PAI. Prosedur pengumpulan data yang digunakan adalah observasi, wawancara dan dokumentasi.Secara keseluruhan siswa di SDN Tambakrejo 03 Semarang sudah mengamalkan sila kesatu Pancasila dengan baik. Terbukti siswa menjadi lebih religius, disiplin, toleransi saling menghargai dan menghormati satu sama lain setelah diadakannya kegiatan shalat dzuhur berjamaah.
\end{abstract}

\section{A B S T R A C T}

The background that encourages this research is that the researcher wants to know how to practice the precepts of one Pancasila through the midday prayer as a vehicle for character education at SDN Tambakrejo 03 Semarang. As well as what character values are found by holding the midday prayer in congregation at SDN Tambakrejo 03 Semarang. Descriptive qualitative research method. Sources of research data are PAI students and teachers. Data collection procedures used were observation, interviews and documentation. Overall students at SDN Tambakrejo 03 Semarang had practiced the precepts of one Pancasila well. Proven students become more religious, disciplined, mutual respect and respect for each other after holding the dzuhur prayer. 


\section{Pendahuluan}

Pendidikan adalah usaha sadar dan terencana untuk mewujudkan suasana belajar dan proses pembelajaran agar peserta didik secara aktif mengembangkan potensi dirinya untuk memiliki kekuatan spiritual keagamaan, pengendalian diri, kepribadian, kecerdasan, akhlak mulia, serta keterampilan yang diperlukan dirinya, masyarakat, bangsa dan Negara (Pasal 1, UU Nomor 20 Tahun 2003 tentang Sistem Pendidikan Nasional).

Di era yang modern yang semakin canggih ini. Penerapan pendidikan tidak hanya berupa akademik saja. Akan tetapi berasal juga dari kegiatan non akademik. Salah satunya dengan kegiatan literasi di sekolah. Seperti di SDN Tambakrejo 03 Semarang. Dengan kesibukan para orang tua yang sibuk bekerja. Pihak sekolah sadar betul dengan semua itu. Pembentukan karakter yang religius sesuai dengan pengamalan sila 1 Pancasila harus diterapkan sejak dini. Penerapan pendidikan dapat diterapkan baik dari kegiatan akademik maupun non akademik. Salah satunya dengan kegiatan literasi di sekolah. Seperti di SDN Tambakrejo 03 Semarang. Dengan kesibukan para orang tua yang sibuk bekerja. Pihak sekolah sadar betul dengan semua itu. Pembentukan karakter yang religius sesuai dengan pengamalan sila 1 Pancasila harus diterapkan sejak dini.

Salah satu nilai yang ada di dalam pendidikan karakter adalah nilai religius. Nilai ini sangat erat kaitannya dengan nilai keagamaan karena nilai religius bersumber dari agama dan mampu merasuk kedalam jiwa seseorang. Nilai religius bersifat mutlak dan abadi, serta bersumber pada kepercayaan dalam diri manusia. Di dalam pancasila, karakter nilai religius terletak pada sila kesatu yang berbunyi "Ketuhanan Yang Maha Esa". Jika diartikan Ketuhanan Yang Maha Esa bukan berarti Tuhan Yang Satu atau Tuhan yang jumlahnya hanya satu. Melainkan Ketuhanan Yang Maha Esa berarti sifat-sifat luhur atau mulia Tuhan yang mutlak harus ada. Jadi yang ditekankan pada sila kesatu dari pancasila adalah sifat-sifat luhur mulia, bukan Tuhannya. Indonesia memiliki agama yang beraneka ragam. Keanekaragaman ini lah yang membuat negara Indonesia memberi jaminan kebebasan kepada setiap penduduk untuk memeluk agama sesuai dengan keyakinan agama masing-masing.

Berbicara tentang agama dan religius, kiranya kita tidak akan terlepas dari yang namanya ibadah. Ibadah merupakan sesuatu yang wajib dilakukan bagi umat beragama. Agama manapun mengajarkan untuk beribadah. Tidak terkecuali agama islam. Agama islam mengajarkan untuk beribadah kepada Allah SWT yaitu salah satunya dengan shalat. Shalat merupakan rukun islam yang kedua setelah syahadat. Setiap umat islam wajib untuk menjalankan ibadah ini. Tidak terkecuali anak SD. Meskipun masih kecil tapi wajib untuk menjalankan ibadah shalat.

Ada banyak macam shalat. Baik shalat fardhu atau shalat sunnah. Shalat fardhu yang wajib dilakukan adalah subuh, maghrib, isya' dan subuh. Apabila meninggalkan akan mendapat dosa. Melaksanakan ibadah shalat akan lebih baik jika dilakukan secara berjamaah.

Program shalat dzuhur berjamaah ini dibuat oleh guru Pendidikan Agama Islam yaitu Bapak Mustajab. Dan disetujui oleh semua guru di SDN Tambakrejo 03 Semarang. Program ini berlaku untuk kelas 3 sampai kelas 6. Pelaksaanya dilakukan di masjid dekat SDN Tambakrejo 03 Semarang. Karena keterbatasaan fasilitas yang dimiliki oleh pihak sekolah. Maka pelaksanaan kegiatan ini dilakukan di masjid dekat sekolah. Diharapkan dengan diadakannya program ini. Siswa dapat mewujudkan pengamalan sila kesatu Pancasila melalui shalat dzuhur berjamaah baik di sekolah ataupun di lingkungan rumah. Program shalat dzuhur berjamaah ini juga dapat membentuk karakter siswa yang religius,disiplin,toleransi, saling menghargai dan menghormati berdasarkan sila kesatu Pancasila yaitu Ketuhanan Yang Maha Esa.

Program shalat dzuhur berjamaah yang dibuat oleh guru ini bertujuan untuk membentuk siswa yang religius berdasarkan sila kesatu Pancasila. Shalat dzuhur yang bertepatan dengan jam 12 siang, membuat pihak sekolah membuat program ini. Karena jika tidak dilaksanakan program ini. Dikhawatirkan siswa tidak melakukan ibadah shalat dzuhur. Dengan pembiasaan di sekolah melalui shalat dzuhur berjamaah, siswa diharapkan dapat beribadah tepat waktu. Tidak hanya di sekolah saja akan tetapi dapat dibiasakan di lingkungan sekitar juga ketika di rumah. Tidak hanya shalat dzuhur berjamaah saja, akan tetapi shalat fardhu yang lain baik shalat subuh shalat azhar shalat maghrib shalat isya dapat dilakukan secara berjamaah.

Pelaksanaan shalat dzuhur berjamaah membuat siswa tidak akan ketinggalan shalat, karena sudah dijadwal oleh guru. Kegiatan pelaksanaan shalat secara berjamaah mempunyai banyak pahala dibandingkan melakukan shalat dzuhur secara sendiri. Hal ini juga membuat guru berfikir jika tidak diadakan program shalat dzuhur berjamaah ini. Ketika siswa sudah pulang ke rumah mereka akan langsung pergi main tanpa shalat dzuhur terlebih dahulu.

Pembangunan karakter yang merupakan upaya perwujudan amanat Pancasila dan Pembukaan UUD 1945 dilatarbelakangi oleh realita permasalahan kebangsaan yang berkembang saat ini, seperti 
disorientasi dan belum dihayatinya nilai-nilai Pancasila; bergesernya nilai etika dalam kehidupan berbangsa dan bernegara; memudarnya kesadaran terhadap nilai-nilai budaya bangsa; ancaman disintegrasi bangsa; dan melemahnya kemandirian (Daryanto, 2013: 41).

Pancasila memiliki karakteristik yang unik yang menyangkut kedudukan, fungsi, dan peran dengan berbagai sebutan khusus, yaitu : nilai-nilai luhur, falsafah, pandangan hidup, ideologi, moral, kepribadian bangsa dan " tanah air mental ", dasar negara, landasan ideal, dasar kerohanian, dan sumber tertib hukum (Sumber dari segala sumber hukum) (Soegeng ,2015: 64).

Sebagaimana telah disebut, Pancasila (walaupun memuat unsur Ketuhanan Yang Maha Esa), bukanlah agama dan agama bukanlah Pancasila. Ketuhanan di dalam Pancasila tidaklah identik dengan ketuhanan dalam agama-agama. Ketuhanan dalam Pancasila lebih merupakan religi, yaitu jiwa dan semangat agama-agama, yang menyatukan segenap iman keagamaan dan aliran kepercayaan kepada Tuhan Yang Maha Esa. Agama dan kepercayaan bisa berbeda-beda tetapi religi (jiwa dan semangat iman terhadap Tuhan Yang Maha Esa) tetap sama. Di dalam Pancasila tidak ada diskriminasi agama-agama dan aliran kepercayaan kepada Tuhan Yang Maha Esa; masing-masing memiliki posisi yang sama di hadapan hukum dan negara (Soegeng, 2015: 83).

Pancasila adalah dasar filsafat negara Republik Indonesia yang resmi disahkan oleh PPKI pada tanggal 18 Agustus 1945 dan tercantum dalam pembukaan UUD 1945, diundangkan dalam Berita Republik Indonesia tahun II No. 7 bersama-sama dengan batang tubuh UUD 1945 (Kaelan,2016:1). Secara fungsional, Pancasila sebagai: falsafah atau ideologi bangsa, kepribadian bangsa, jalan hidup bangsa/cara hidup bangsa, weltanschuung (Jerman), way of life (Inggris), staafsfundamenteelnorm (Belanda) (Soegeng, 2015: 49).

Pancasila sebagai dasar negara sering disebut dasar falsafah negara (dasar filsafat negara/philosophidche grondslag) dari negara, ideologi negara (staatsidee). Dalam hal ini, Pancasila dipergunakan sebagai dasar mengatur pemerintahan negara. Dengan kata lain, Pancasila digunakan sebagai dasar untuk mengatur penyelenggaraan negara (Widodo, 2015: 123).

Dari beberapa pendapat diatas, dapat disimpulkan bahwa Pancasila adalah filsafat atau ideologi bangsa Indonesia, kepribadian bangsa dan menjadi dasar bagi Negara yang tercantum dalam pembukaan UUD 1945 yang dipergunakan untuk mengatur pemerintahan negara

Sila Ketuhanan Yang Maha Esa ini nilai-nilainya meliputi dan menjiwai keempat sila lainnya. Dalam sila Ketuhanan Yang Maha Esa terkendung nilai bahwa negara yang didirikan adalah sebagai pengejawantahan tujuan manusia sebagai makhluk Tuhan Yang Maha Esa. Oleh karena itu segala hal yang berkaitan dengan pelaksanaan dan penyelenggaraan negara bahkan moral negara, moral penyelenggaraan negara, politik negara, pemerintahan negara, hukum dan peraturan perundangundangan negara, kebebasan dan hak asasi warga negara harus dijiwai nilai-nilai Ketuhanan Yang Maha Esa (Kaelan, 2016: 72).

Sila pertama ini memang diakui baik secara langsung maupun tidak langsung adalah cerminan dari ajaran Islam. Tuhan dalam agama Islam adalah Esa, tidak ada yang menandingi ataupun menyeku tui-Nya. Ketuhanan Yang Maha Esa mengandung arti bahwa meskipun Indonesia bukan negara agama, tetapi agama merupakan nilai luhur yang dijunjung tinggi dalam penyelenggaraan negara. Penduduk yang beragama tentu memiliki ajaran luhur yang menjadikan pemeluknya selalu berada dalam kebaikan dan kebenaran selama mengikuti ajaran agamanya (Hamka, 2011: 209).

1. Implementasi Pancasila

Muhammad Anwar Rubai, Dwi Utami (2018: 310-311) mengungkapkan implementasi Pancasila dalam kehidupan sangat penting dilakukan agar setiap warga negara untuk menjunjung tinggi agama dan kepercayaan terhadap Tuhan Yang Maha Esa. Setiap warga negara diharapkan mempunyai keyakinan akan Tuhan yang menciptakan manusia dan dunia serta isinya. Keyakinan akan Tuhan Yang Maha Esa

Darmadi (2014: 3215) mengungkapkan pengamalan Pancasila yang ditetapkan berdasarkan ketetapan MPR Nomor II/MPR/1978 tentang pedoman penghayatan dan pengamalan Pancasila, yaitu: (1) Percaya dan takwa kepada Tuhan Yang Maha Esa sesuai dengan agama dan kepercayaan masing-masing menurut dsar kemanusiaann yang adil dan beradap. (2) Hormat menghormati dan bekerja sama antara pemeluk agama dan penganut kepercayaa yang berbeda-beda sehingga terbina kerukunan hidup, (3) saling menghormati dan kebebasan menjalankan ibadah sesuai dengan agama dan kepercayannya. (4) Tidak memaksanakan suatu agama dan kepercayaan kepada orang lain.

2. Nilai-nilai yang Terkandung dalam Sila Kesatu Pancasila

Dalam sila kesatu berbunyi " Ketuhanan Yang Maha Esa" terkandung nilai-nilai religius diantaranya: a) Keyakinan terhadap adanya Tuhan Yang Maha Esa dengan sifat-sifatnya yang maha sempurna, dan b) Ketaqwaan terhadap Tuhan Yang Maha Esa, yakni menjalankan semua perintahnya dan menjauhi segala larangannya (Widodo, 2015: 116). 
Widodo (2015: 121) mengungkapkan bahwa nilai kerohanian dapat dirinci menjadi 4 yaitu: a) Nilai kebenaran yang bersumber kepada unsur rasio manusia, budi, dan cipta, b) Nilai keindahan yang bersumber pada unsur rasa atau instuisi, c) Nilai moral yang bersumber pada unsur kehendak manusia atau kemauan (Karsa, etika), dan d) Nilai religi, yang merupakan nilai Ketuhanan merupakan nilai kerokhanian yang tertinggi dan mutlak. Nilai ini bersumber kepada keyakinan dan keimanan manusia terhadap adanya Tuhan.

Makna sila kesatu Pancasila bermakna pengakuan terhadap adanya Tuhan dan manusia sebagai CiptaaNya, maka harus berbakti dan meluhurkanNya sebagai wujud pengakuan tersebut serta melaksanakannya dalam kehidupan sehari-hari (iman, taqwa). Hal ini berarti bahwa bukan hanya bangsa Indonesia hendaknya bertuhan. Hal itu juga berarti pengakuan terhadap paham ketuhanan, sebagai manusia religius dan menolak paham ateis dengan segala bentuk kemusrikan. Namun demikian, hal ini tidak berarti bahwa setiap orang harus beragama, melainkan setiap orang hendaknya bertuhan. Sekalipun orang bertuhan juga beragama (Soegeng,2015:68).

Pendidikan karakter adalah sebuah usaha untuk mendidik anak-anak agar dapat mengambil keputusan yang bijak dan mempraktikkannya dalam kehidupan sehari-hari, sehingga mereka dapat memberikan kontribusi yang positif kepada lingkungannya (Megawati, 2004: 95).

Putri (2018:40) mengatakan bahwa pendidikan karakter adalah adalah sesuatu yang dilakukan oleh guru, yang mampu mempengaruhi karakter peseta didik. Guru membantu membentuk watak peserta didik. Pendidikan karakter menanamkan kebiasaan tentang hal mana yang baik sehingga peserta didik menjadi paham tentang mana yang benar dan salah, mampu merasakan nilai yang baik dan bisa melakukannya.

Dari pendapat diatas, dapat disimpulkan bahwa pendidikan karakter adalah usaha yang dilakukan oleh guru untuk mendidik anak di SD untuk membentuk watak peserta didik dengan menanamkan kebiasaan yang baik di sekolah. Sehingga siswa menjadi paham dan melakukannya dalam kehidupan sehari-hari.

Karakter-karakter yang terdapat dalam pendidikan karakter bangsa menurut Kemendiknas (2010) nilai-nilai luhur sebagai pondasi karakter ada 18 unsur, akan tetapi dalam penelitian ini lebih memfokuskan pada beberapa karakter dari kemendiknas yang terkait dengan judul penelitian diantaranya : a) Religius, yaitu sikap dan perilaku yang patuh dalam melaksanakan ajaran agama yang dianutnya, toleran terhadap pelaksaan ibadah agama lain, dan hidup rukun dengan pemeluk agama lain, b) Toleransi, yaitu sikap dan tindakan yang menghargai perbedaan agama, suku, etnis, pendapat, sikap, dan tindakan orang lain yang berbeda dengan dirinya, dan c) Disiplin, tindakan yang menunjukan perilaku tertib dan patuh pada berbagai ketentuan dan peraturan.

Menurut bahasa, shalat adalah doa. Menurut istilah syara', shalat ialah ibadah kepada Allah dalam bentuk perkataan dan perbuatan yang dimulai dengan takbir dan diakhiri dengan salam yang dilakukan menurut syarat-syarat yang telah ditentukan oleh syara' (Syaifurarahman, 2018: 35).

Zaitun dan Siti Habibah (2013:154) mengatakan bahwa secara etimologis shalat berasal dari bahasa Arab yang bermakna doa. Ini bermakna perkataan-perkataan yang ada di dalam shalat berarti doa memohon kebajikan dan pujian. Secara hakikat shalat berarti berharap kepada Allah dan takut kepadaNya serata menimbulkan keagungan, kebesaran, dan kesempurnaan kepada Allah SWT.

Adapun di sisi syara' shalat memiliki beberapa pengertian antara lain : shalat adalah beberapa perkataan dan perbuatan yang dimulai dengan takbir dan diakhiri dengan salam yang dengannya kita beribadat kepada Allah, menurut syarat-syarat yang telah ditentukan, shalat juga bermakna menghadapkan hati kepada Allah dengan penuh rasa takut dan hormat pada keagungan dan kebesaranNya dan kesempurnaan kuasa-Nya, makna lainya bahwa menampakkan hajat dan keperluan kita kepada Allah yang telah sembah dengan perkataan dan pekerjaan atau dengan keduanya, shalat juga berarti menghadap hati kepada Allah dengan kusyu di hadapan-Nya dan ikhlas karena-Nya serta hadir hati dalam zikir, berdoa dan memuji-Nya.

Sedangkan Kata jamaah diambil dari kata al-ijtima' yang berarti kumpul. Jamaah berarti sejumlah orang yang dikumpulkan oleh satu tujuan. Shalat jamaah adalah shalat yang dikerjakan secara bersamasama, sedikitnya dua orang, yaitu yang satu sebagai imam dan yang satu lagi sebagai makmum. Berarti dalam shalat berjamaah ada sebuah ketergantungan shalat makmum kepada shalat imam berdasarkan syarat-syarat tertentu. Menurut Kamus Istilah Fiqih shalat jamaah adalah shalat yang dikerjakan secara bersama-sama, salah seorang diantaranya sebagai imam dan yang lainnya sebagai makmum. Shalat berjamaah adalah beberapa perkataan dan perbuatan yang dimulai dengan takbir dan diakhiri dengan salam, dengan maksud untuk beribadah kepada Allah, menurut syarat-syarat yang sudah ditentukan dan pelaksanaannya dilakukan secara bersama-sama, salah seorang di antaranya sebagai imam dan yang lainnya sebagai makmum (Manshur, 2007: 66). . 
Shalat jamaah adalah shalat bersama-sama,sekurang-kurangnya terdiri dari dua orang, yaitu imam dan makmum. Hukumnnya sunah muakkad dan cara mengejakannya imam berdiri di depan dan makmum berdiri di belakangnya. Makmum harus mengikuti imam dan tidak boleh mendahuluinya (Syaifurarahman, 2018: 93).

Berdasarkan pendapat dari beberapa ahli, dapat disimpulkan bahwa shalat berjamaah adalah shalat yang dikerjakan secara bersama-sama oleh sekurang-kurangnya oleh 2 orang sebagai imam dan makmum yang diawali dengan takbir dan diakhiri dengan salam. Shalat ini tidak dapat dikerjakan sendiri.

Syaifurarahman (2018: 42) mengungkapkan bahwa rukun shalat yang harus dilakukan diantaranya: 1) Niat mengerjakan shalat, 2) Berdiri tegak bagi yang kuasa ketika shalat fardhu. Boleh sambil duduk atau berbaring bagi yang sedang sakit, 3) Takbiratul ihram sebagai pembuka semua shalat, 4) Membaca surah Al-Fatihah pada tiap-tiap rakaat, 5) Rukuk dengan tuma'nina (diam sebentar), 6) I'tidal swngan tumaninah, 7) Sujud dua kali dengan tuma'ninah, 8) Duduk antara dua sujud dengan tuma'ninah, 9) Duduk tasyahud akhir dengan tuma'ninah, 10) Membaca tasyahud akhir, 11) Membaca shalawat atas Nabi pada tasyahud akhir, 12) Melakukan salam yang pertama ke kanan, 13) Tertib: berurutan mengerjakan rukun-rukun tersebut.

Berdasarkan uraian konteks penelitian di atas maka penelitian difokuskan pada: Bagaimana pengamalan sila kesatu pancasila melalui shalat dzuhur berjamaah SDN Tambakrejo 03 Semarang dan Karakter apa saja yang dikembangkan melalui pengamalan sila kesatu pancasila melalui shalat dzuhur berjamaah SDN Tambakrejo 03 Semarang.

\section{Metode}

Pada penelitian ini, peneliti menggunakan pendekatan kualitatif. Penelitian ini melihat secara langsung untuk menganalisis pengamalan sila kesatu Pancasila melalui shalat dzuhur berjamaah di SDN Tambakrejo 03 Semarang. Penelitian ini dilaksanakan di SDN Tambakrejo 03 Kecamatan Gayamsari Kota Semarang Jawa Tengah.

Jenis penelitian yang digunakan adalah deskriptif. Yang ditulis dalam bentuk narasi yang menggambarkan keadaan siswa dengan menganalisis. Tujuan ini adalah untuk membantu pembaca mengetahui apa yang terjadi di lokasi yang digunakan untuk penelitian. Seperti peristiwa atau aktifitas apa saja yang terjadi selama penelitian berlangsung. Sedangkan tujuan penelitian ini adalah Mendeskripsikan pengamalan sila kesatu pancasila melalui shalat dzuhur berjamaah SDN Tambakrejo 03 Semarang dan Menemukan / meyadari nilai karakter yang dikembangkan melalui pengamalan sila kesatu pancasila melalui shalat dzuhur berjamaah SDN Tambakrejo 03 Semarang. Sumber data dibagi menjadi 2 yaitu data primer berupa wawancara observasi dan data sekunder berupa dokumentasi. . Adapun sumber data tersebut adalah sebagai berikut:

1. Sumber Data Primer

Sumber data ini diperoleh dari observasi wawancara yang dilakukan melalui informan dan dicatat secara tertulis rekaman melalui video atau audio, dan dokumentasi foto.

2. Sumber Data Sekunder

Sumber data yang diperoleh adalah foto-foto dokumentasi selama penelitian dilaksanakan.

Prosedur pengumpulan data dalam penelitian ini ada 3 cara yaitu:

1. Observasi

Observasi dalam penelitian ini ditujukkan untuk semua kelas 3 sampai kelas 6 yang mengikuti shalat dzuhur berjamaah di sekolah yang dilaksanakan di masjid di wilayah sekitar sekolah.

2. Wawancara

Wawancara yang dilakukan oleh peneliti ini ditujukkan untuk guru Pendidikan Agama Islam untuk mengetahui pengamalan sila 1 Pancasila melalui shalat dzuhur berjamaah sebagai wahana pendidikan karakter di SDN Tambakrejo 03 Semarang.

3. Dokumentasi

Dokumentasi dalam penelitian ini berisi tulisan, catatan, gambar, audio, video selama kegiatan berlangsung. Dokumen ini berisi informasi yang didapat dari informan. Dokumen foto atau video diambil pada saat kegiatan shalat dzuhur berjamaah berlangsung, wawancara bersama guru agama islam. 


\section{Hasil dan Pembahasan}

Pendidikan karakter adalah sebuah usaha untuk mendidikan anak-anak agar dapat mengambil keputusan yang bijak dan mempraktikkannya dalam kehidupan sehari-hari, sehingga mereka dapat memberikan kontribusi yang positif kepada lingkungannya (Ratna Megawani, 2004: 95)

Dini Palupi Putri (2018: 40) Pendidikan karakter adalah adalah sesuatu yang dilakukan oleh guru, yang mampu mempengaruhi karakter peseta didik. Guru membantu membentuk watak peserta didik. Pendidikan karakter menanamkan kebiasaan tentang hal mana yang baik sehingga peserta didik menjadi paham tentang mana yang benar dan salah, mampu merasakan nilai yang baik dan bisa melakukannya.

Karakter siswa yang baik harus dididik sejak dini. Tidak hanya di rumah saja akan tetapi juga di sekolah. Salah satu upaya sekolah dalam memberikan pendidikan karakter siswa yang baik dengan diadakannya program shalat dzuhur berjamaah di sekolah. Upaya ini dibuat oleh bapak ibu guru SDN Tambakrejo 03 Semarang. Diharapkan dengan diadakannya program ini, siswa berubah menjadi lebih religius setelah diadakannya kegiatan shalat dzuhur berjamaah di sekolah sesuai dengan pengamalan sila kesatu Pancasila. Selain karakter religius, dengan diadakannya kegiatan shalat dzuhur berjamaah. Karakter yang terlihat dari siswa adalah disiplin, saling menghargai dan menghormati, toleransi. Siswa dibudayakan untuk berperilaku religius, toleransi dan saling menghargai sesuai dengan pengamalan sila kesatu Pancasila melalui kegiatan shalat dzuhur berjamaah ini.

Penelitian dilaksanakan di SDN Tambakejo 03 Semarang di Jalan Tenggang Tambakrejo, Kecamatan Gayamsari, Kota Semarang yang berlangsung pada tanggal 26 Agustus sampai 30 Agustus 2019. Penelitian ini dilaksanakan dengan bantuan partisipasi seluruh siswa dari kelas III sampai kelas VI baik secara langsung maupun tidak langsung.

SDN Tambakrejo 03 Semarang adalah SD yang terletak di kawasan Semarang Utara yang dekat dengan tambak. Sekolah ini berdiri diatas lahan $960 \mathrm{~m}^{2}$ dengan status kepemilikan Pemerintah Kota Semarang. Sekolah ini sudah terakreditasi A. SDN Tambakrejo 03 Semarang ini terdiri dari 12 tenaga pengajar termasuk satu guru Agama Islam, satu guru Penjasorkes, 1 tenaga administrasi, dan 1 tenaga kebersihan. Sekolah ini dibawah kepemimpinan kepala sekolah Ibu MM. Sri Wilujeng, S.Pd. SDN Tambakrejo 03 Semarang mempunyai 5 bangunan kelas yang terdiri atas 2 lantai. Lantai diatas merupakan ruangan kelas III, IV, V, VI. Sedangkan ruangan bawah ditempati untuk kelas I atau II. Karena keterbatasan ruangan, menyebabkan kelas I dan kelas II ruangannya bergantian. Dimulai kelas I dari jam 07.00 - 10.00 WIB kemudian dilanjutkan dengan kelas II dari jam 11.00 - 14.00 WIB.

Disamping itu, SDN Tambakrejo 03 Semarang juga mempunyai 1 bangunan perpustakaan yang bersebelahan dengan kelas I. Ruang guru yang menjadi 1 dengan ruang Kepala Sekolah dan untuk menerima tamu, kantin, 2 kamar mandi, parkir motor, lapangan untuk berolahraga dan melaksanakan upacara. Untuk kegiatan shalat dzuhur berjamaah sendiri, tempat pelaksanaaanya di masjid disekitar SDN Tambakrjeo 03 Semarang. Karena keterbatasan fasllitas sarana dan prasarana, akhirnya shalat dzuhur berjamaah dilaksanakan di masjid dan dilaksanakannya bersama sebagian warga sekitar masjid di area SDN Tambakrejo 03 Semarang.

Penemuan hasil observasi dalam pelaksanaan shalat dzuhur berjamaah sudah berjalan dengan baik, tertib dan disiplin. Ketika adzan berkumandang, guru akan menghentikan kegiatan pembelajaran dan meminta siswa untuk bergegas melaksanakan shalat dzuhur berjamaah. Siswa dengan antusias yang tinggi berlari ke masjid dengan membawa perlengkapan shalat masing-masing dari rumah. Siswa akan mengantri untuk wudhu dengan tertib. Tidak saling bercanda dan bermain sendiri. Untuk kelas tinggi, ketika wudhu, siswa sudah bisa melafalkan bacaan niat wudhu dan rukun-rukun ketika berwudhu. Akan tetapi untuk kelas rendah, ada beberapa yang belum bisa melafalkan bacaan niat wudhu beserta rukunrukun dalam melaksanakan wudhu.

Setelah melaksanakan wudhu, siswa akan mengatur barisan sendiri dengan tertib. Terutama kelas tinggi akan berada dibarisan paling depan. Mereka tertib ketika mengatur barisan dalam shalat. Ketika pelaksanaan shalat dzuhur berjamaah. Guru mendampingi siswa serta mengikuti shalat dzuhur berjamaah. Ada beberapa siswa yang tidak membawa perlengkapan shalat sendiri dari rumah. Mereka akan meminjam perlengakapan shalat di masjid. Dalam pelaksanaanya, dipimpin oleh imam yang berbeda-beda setiap hari. Siswa yang berada di barisan paling depan cenderung sangat tenang dan tertib ketika dilaksanakannya shalat. Akan tetapi siswa yang berada di barisan belakang, mereka sesekali bercanda dan mengobrol.

Siswa-siswi di kelas tinggi sudah megetahui bacaan-bacaan dalam setiap rukun shalat. Akan tetapi untuk kelas rendah seperti kelas III. Mereka masih belum terlalu paham dengan bacaan-bacaan setiap rukun shalat. Meskipun begitu, mereka semua terlihat sangat atusias dan semangat mengikuti gerakan imam ketika berlangsungnya shalat dzuhur berjamaah. 
Dalam mengembangkan pendidikan karakter sesuai dengan pengamalan sila kesatu Pancasila. Guru Pendidikan Agama Islam dan semua guru membentuk program shalat dzuhur berjamaah dan disetujui oleh kepala sekolah SDN Tambakrejo 03 Semarang. Penelitian ini dilakukan pada tanggal 26 Agutus 2019 sampai 30 Agustus 2019. Di dalam penelitian ini dibantu oleh partisipasi seluruh warga SDN Tambakrejo 03 Semarang baik secara langsung maupun tidak langsung. Penelitian ini dilakukan dengan cara melihat aspek-aspek di dalam indikator pengamalan sila kesatu Pancasila melalui shalat dzuhur berjamaah sebagai wahana pendidikan karakter yang ditelaah dari berbagai sumber pengamatan dan wawancara. Dengan begitu dapat diketahui karakter apa saja yang sudah ditemukan melalui pengamalan shalat dzuhur berjamaah.

Peneliti melakukan observasi setiap hari. Dimulai dari hari Senin 26 Agustus 2019 sampai Jumat 30 Agustus 2019. Shalat dzuhur berjamaah hanya dilaksanakan setiap Senin - Kamis karena Jum'at dan Sabtu siswa pulang lebih awal yaitu pukul 10.00 WIB. Shalat dzuhur berjamaah ini dilaksankan di masjid dekat SDN Tambakrejo 03 Semarang yang diikuti oleh seluruh warga sekolah. Dari kelas III sampai kelas IV beserta bapak ibu guru dan juga warga sekitar SDN Tambakrejo 03 Semarang. Selain shalat dzuhur berjamaah, kegiatan program pengamalan sila kesatu di SDN Tambakrejo diantaranya pembacaan asmaul husna, pembacaan surat-surat pendek, pesantren kilat, peringatan hari besar agama. Guru berharap dengan diadakannya kegiatan shalat dzuhur berjamaah ini, siswa terbiasa melaksanakan. menjadi lebih religius, disiplin, toleransi, bersikap saling menghargai dan menghormati satu sama lain, tertib. Kereligiusan siswa dapat terlihat ketika siswa menjadi rutin mengikuti shalat dzuhur berjamaah. Perubahan sikap yang dulunya tidak pernah melaksanakan shalat dzuhur, setelah sekolah mengadakan kegiatan shalat dzuhur berjamaah. Siswa menjadi rutin mengikuti shalat dzuhur berjamaah.

Kedisiplinan siswa terlihat ketika adzan berkumandang siswa langsung berlari untuk mengikuti shalat dzuhur berjamaah. Shalat dzuhur berjamaah ini dilaksanakan dengan sangat antusias. Tidak ada yang terlambat dan selalu tepat waktu. Toleransi siswa juga telihat ketika siswa saling menghargai perbedaan yang ada antara satu sama lain dan juga saling mengehargai satu sama lain. Sikap menghargai dan menghormati yang terlihat adalah ketika siswa sedang wudhu, mereka akan saling menghargai dengan cara antri. Pada saat berlangsungnya kegiatan shalat dzuhur berjamaah, siswa mengikuti dengan baik dan tertib.

\section{Simpulan dan Saran}

Berdasarkan hasil penelitian penelitian dan pembahasam pengamalan sila kesatu Pancasila melalui shalat dzuhur berjamaah sebagai wahana pendidikan karakter SDN Tambakrejo 03 Semarang dapat diperoleh kesimpulan bahwa pengamalan sila kesatu Pancasila sudah baik. Hal ini dibuktikan dengan diadakannya program kegiatan shalat dzuhur berjamaah yang dibuat oleh bapak ibu guru SDN Tambakrejo 03 Semarang dan diikuti oleh semua siswa kecuali siswa kelas 1 dan kelas II. Dan juga diikuti oleh bapak ibu guru beserta sebagian warga sekitar SDN Tambakrejo 03 Semarang.

Dari hasil observasi yang dilakukan, karakter yang terlihat diantaranya religius, disiplin, toleransi, dan sikap saling menghargai serta menghormati sesuai dengan pengamalan sila kesatu Pancasila. Saat berlangsungnya shalat dzuhur berjamaah. Sebagian sudah paham dan mengerti bacaan rukun-rukun wudhu dan shalat. Akan tetapi, sebagian juga belum paham dan mengerti bacaan rukun-rukun wudhu dan shalat. Terutama untuk kelas rendah yaitu kelas III. Ketika pelaksanaan shalat dzuhur berjamaah, siswa sudah tertib, tidak bermain sendiri, tidak bercanda sendiri. Meskipun barisan paling akhir ada beberapa yang bermain sendiri, mengobrol dan bercanda sendiri. Akan tetapi, secara keseluruhan pelaksanaan shalat dzuhur berjamaah sudah berjalan dengan baik dan tertib. Dan program kegiatan shalat dzuhur berjamaah mampu membentuk karakter siswa yang lebih religius, disiplin, toleransi, saling menghargai dan menghormati satu sama lain sesuai dengan pengamalan sila kesatu Pancasila.

Berdasarkan penelitian diatas, maka ada beberapa saran yang bisa dipaparkan dari penelitian ini yaitu : 1) Hendaknya semua guru mengikuti kegiatan shalat dzuhur berjamaah. Bukan hanya perwakilan saja. 2) Bagi guru diharapkan selalu dapat memberikan contoh pengamalan sila kesatu Pancasila. 3) Bagi sekolah diharapkan dapat meningkatkan dan mengembangkan lagi program-program yang berhubungan dengan pendidikan karakter siswa terutama sesuai dengan pengamalan sila kesatu Pancasila. 4) Bagi siswa diharapkan agar lebih disiplin, tertib dalam mengikuti shalat dzuhur berjamaah. 5) Bagi siswa hendaknya selalu membawa perlengkapan shalat dzuhur berjamaah sendiri dari rumah 6) Bagi peneliti lain hasil dari penelitian dapat dikembangkan dengan penelitian yang serupa dengan lebih mendetail lagi. 


\section{Daftar Rujukan}

Abdurraziq, Mahir Manshur. 2007. Mukjizat Shalat Berjamaah. Yogyakarta: Mitra Pustaka

Aulia, Listya Rani. 2016. Implementasi Nilai Religius dalam Pendidikan Karakter bagi Peserta Didik di Sekolah Dasar Juara Yogyakarta. Jurnal Kebijakan Pendidikan. Vol.5(3) : 316.

Aulia, Listya Rani. 2016. Implementasi Nilai Religius dalam Pendidikan Karakter bagi Peserta Didik di Sekolah Dasar Juara Yogyakarta. Jurnal Kebijakan Pendidikan. Vol.5(3) : 318.

Daryanto dan Suryati Darmiatun. 2013. Implementasi Pendidikan Karakter di Sekolah. Yogyakarta: Gava Meda.

El-Fati, Syaifurrahman. 2018. Panduan Shalat. Jakarta: Wahyuqolbu.

Gunawan, Heri. 2012. Pendidikan Karakter \& Konsep Implementasi. Bandung: Alfabeta.

Haq, Hamka. 2011. Pancasila 1 Juni \& Syariat Islam. Bandung: RM Books.

Kaelan. 2016. Pendidikan Pancasila. Yogyakarta: Paradigma.

Kaelan dan Achmad Zubaidi. 2012. Pendidikan Kewarganegaraan. Yogyakarta: Paradigma.

Kesuma, Dharma, Cepi Triatna dan Johar Permana. 2013. Pendidikan Karakter Kajian Teori dan Praktis di Sekolah. Bandung: PT Remaja Rosdakarya.

Megawati, Ratna. 2004. Pendidikan Karakter; Solusi Yang Tepat untuk Membangun Bangsa. Bogor: Indonesia Heritage Foundation.

Moleong, Lexy J. 2010. Metodologi Penelitian Kualitatif. Bandung: PT Remaja Rosdakarya.

Muhammad Anwar Rube'i 2018 . Pendidikan Sila Ketuhanan Yang Maha Esa Pada Mata Pelajaran Pendidikan Pancasila dan Kewarganegaraan Kelas XI SMA Negeri 1 Toho Kabupaten Mempawah. Jurnal Pendidikan Kewarganegaraan. Vol.2(1) : 313.

Nasional, D. P. (2006). Peraturan Menteri Pendidikan Nasional Republik Indonesia No.22 tahun 2006 tentang Standar Isi. Jakarta: Depdiknas.

Patilima, Hamid.2007. Metode Penelitian Kualitatif.Bandung: Alfabet.

Putri, Dini Palupi. 2018 . Pendidikan Karakter pada Usia Anak SD di Era Digital. Jurnal Pendidikan Dasar. Vol.2(1) : 40 .

Soegeng, A.Y. 2015. Etika Pancasila. Yogyakarta: Magnum Pustaka Media.

Sugiyono. 2013. Metode Penelitian Pendidikan (Pendekatan Kuantitatif, kualitatif, dan R\&D). Bandung: Alfabeta.

Sugiyono. 2014. Metode Penelitian Pendekatan Kuantitatif, Kualtatif dan R\&D. Bandung: Alfabet.

Widodo, Wahyu, Budi Anwari dan Maryanti. 2015. Pendidikan Kewarganegaraan. Yogyakarta: Andi Publisher. 